\title{
Spontaneous cerebrospinal fluid rhinorrhoea: a rare clinical entity
}

\author{
Kapil Mohan Rajwani, ${ }^{1}$ Mike O'Connell, ${ }^{1}$ Sorin Bucur ${ }^{2}$
}

${ }^{1}$ Brighton and Sussex University Hospitals, Royal Sussex County Hospital, Brighton, UK

${ }^{2}$ Hurstwood Park Neurosciences Centre, West Sussex, UK

\section{Correspondence to} Kapil Mohan Rajwani, kapilrajwani@hotmail.com
CrossMark

To cite: Rajwani KM, O'Connell M, Bucur S. BMJ Case Rep Published online: [please include Day Month Yearl doi:10.1136/bcr-2013202808

\section{DESCRIPTION}

Cerebrospinal fluid (CSF) rhinorrhoea is usually secondary to severe head trauma. Spontaneous CSF leak is an infrequent entity and represents only $4 \%$ of CSF rhinorrhoea cases. ${ }^{1}$

A 70-year-old obese woman (body mass index 36.5) was seen in outpatients with an 8-week history of clear discharge from her left nostril which was worse on exertion. She had a similar episode of left rhinorrhoea 4 months ago, which lasted about 4 weeks; it was self-limiting and resolved without surgical intervention. On endoscopy, a leak was identified just medial to the left middle turbinate.

Electrophoretic analysis of the nasal discharge was positive for Tau protein ( $\beta 2$-transferrin), which is specific to CSF, establishing a diagnosis of CSF rhinorrhoea. A CT cisternogram located the site of the defect (fistula) to the left cribriform plate (figure 1). The patient underwent an endoscopic endonasal fistula repair under general anaesthesia and made an uncomplicated recovery. She was

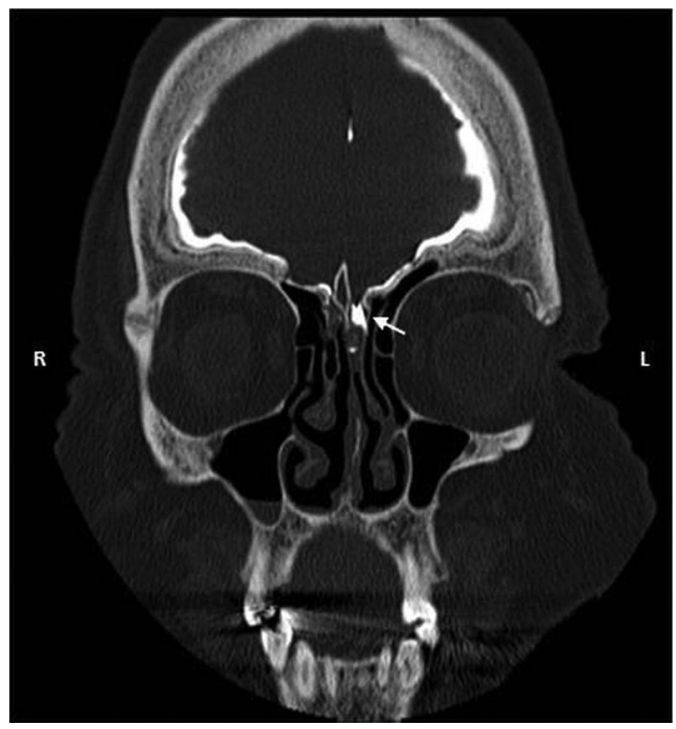

Figure $1 \mathrm{CT}$ cisternogram showing defect in the left cribriform plate (arrow) with leak of contrast into the nose. symptom-free when followed up 1 month postoperative.

Persistent CSF rhinorrhoea is potentially fatal and can lead to meningitis in $50 \%$ of cases. ${ }^{2}$ It is often confused with rhinitis or upper respiratory infection. Spontaneous CSF leaks are more common in obese women and in patients with evidence of raised intracranial pressure. ${ }^{3}$ CT cisternography is the diagnostic radiological investigation of choice as it pinpoints the site of the fistula. ${ }^{12}$ Endoscopic endonasal repair has a high success rate (85-95\%), and in most cases, it has almost completely replaced the intracranial approach. ${ }^{1}$

\section{Learning points}

- Cerebrospinal fluid (CSF) rhinorrhoea should be suspected in patients with persistent unilateral clear nasal discharge.

- The presence of Tau protein ( $\beta 2$-transferrin) in nasal discharge establishes a diagnosis of CSF leak and a CT cisternogram identifies the site of the fistula.

- Endoscopic endonasal fistula repair is safe and has a high success rate.

Contributors KMR wrote the case report. MO and SB reviewed and edited the manuscript.

Competing interests None.

Patient consent Obtained.

Provenance and peer review Not commissioned; externally peer reviewed.

\section{REFERENCES}

1 Lopatin AS, Kapitanov DN, Potapov AA. Endonasal endoscopic repair of spontaneous cerebrospinal fluid leaks. Arch Otolaryngol Head Neck Surg 2003;129:859-63.

2 Kuo W-M, Lin C-R, Shen K-H. Spontaneous CSF rhinorrhea. J Med Sci 2003:23:355-8.

3 Mirza S, Thaper A, McClelland L, et al. Sinonasal cerebrospinal fluid leaks: management of 97 patients over 10 years. Laryngoscope 2005;115:1774-7. 
Copyright 2014 BMJ Publishing Group. All rights reserved. For permission to reuse any of this content visit http://group.bmj.com/group/rights-licensing/permissions.

BMJ Case Report Fellows may re-use this article for personal use and teaching without any further permission.

Become a Fellow of BMJ Case Reports today and you can:

- Submit as many cases as you like

- Enjoy fast sympathetic peer review and rapid publication of accepted articles

- Access all the published articles

- Re-use any of the published material for personal use and teaching without further permission

For information on Institutional Fellowships contact consortiasales@bmjgroup.com

Visit casereports.bmj.com for more articles like this and to become a Fellow 